\title{
More persistent legumes and grasses for oversown tussock country
}

\author{
B.E. ALLAN and J.M. KEOGHAN \\ AgResearch, PO Box 60, Lincoln
}

\section{Abstract}

A grazing trial on oversown tussock country at Tara Hills Research Station, started in 1978 and still continuing, has highlighted short comings of clovers and grasses traditionally used for improvement. In 1984 a wide range of legume and grass germplasm was planted into each of the nine stocking rate/management treatments to identify plant material more persistent than that traditionally used, and investigate specific responses under Extreme (high stocking rate), Optimal (moderate stocking rate and management giving optimum liveweight gain/ha) and Lax (low stocking rate) grazing management. After 6 years none of the 12 white clover, 7 alsike and 9 lotus lines tested persisted significantly better than Grasslands Huia white clover (Trifolium repens). Plant survival and spread of Caucasian clover (Trifolium ambiguum) was exceptional. In terms of persistence and spread this legume ranked first out of the 56 germplasm lines under examination. The 15 ryegrasses examined did not persist better than Grasslands Nui ryegrass (Lolium perenne). However, for Optimal management, many ryegrasses performed better than Nui._Cocksfoot-(Dactylis-glomerata) also performed very well, with Grasslands Wana showing greater persistence under Extreme management than other cocksfoots and ryegrasses. Tall oat grass (Arrhenatherum elatius) was very persistent and like Caucasian clover performed well under all managements. Other grasses tested showed poor persistence, as did the herb sheep's burnet (Sanguisorba minor).

K eywords: Arrhenatherum elatius, Dactylis glomerata. grazing management, high country, persistence, sustainable improvement, Trifolium ambiguum, tussock grasslands

\section{Introduction}

Approximately $20 \%$ of the South Island high country has received some form of pastoral improvement. Of this, $75 \%$ has been achieved by aerial oversowing legumes and grasses, and topdressing with fertiliser (Kerr 1983). Run-holders have tended to use traditional cultivars of white, red, and alsike clovers, and to a lesser extent cocksfoot and ryegrass when improving their tussock grasslands. Where soil and climatic conditions are favourable, these species establish well and result in a dramatic increase in forage production (O'Connor 1967; Vartha \& Clifford 1973).

A long-term grazing trial on improved tussock country at Tara Hills Research Station, (Allan et al. 1992) was started in 1978 with the aim of identifying grazing management strategies for sustainable utilisation of improved tussock grassland. The experiment highlighted problems with persistence of the traditionally used oversown species (Allan et al. 1992). The objective of the present research was to evaluate the potential of a broader range of traditional as well as alternative pasture germplasm (species, types, cultivars and lines), in particular their ability to persist and spread under a range of grazing management and pasture utilisation.

\section{M ethods}

The grazing trial was sited on mid-altitude, shady, Omarama steepland yellow-grey earth at Tara Hills High Country Research Station, near Omarama. The trial compared 3 stocking rates: low or traditional_(2), mextiutim (3) and high (4 SU/ha/year), with 3 management practices at each stocking rate: continuous stocking, alternating grazing ( 2 paddocks with stock shifts every 2-3 weeks) and rotational grazing (6 paddocks with weekly stock shifts). The first six years showed that liveweight gain was optimal with a pasture utilisation per grazing of $60-70 \%$ (achieved at the medium stocking rate), provided a simple form of mob stocking (that is alternative grazing) was undertaken (Allan et al. 1985; Allan \& Keoghan 1989).

Twenty-eight legumes, 27 grasses and 1 herb were evaluated (Table 1). Possible problems with establishment from seed were by-passed by propagating the material in root trainers in a glasshouse, hardening off, and then hand planting the seedlings into the various grazing treatments. Sixteen plants of each of the 56 varieties were planted at $20 \mathrm{~cm}$ spacings into a row that followed the fall-line of the slope of the grazing trial. The 56 rows were randomly arranged within a block to form one replicate measuring $30 \times 15 \mathrm{~m}$. Four replicates were located in each of the nine 1.74 ha grazing treatments contained within the grazing trial, Plantings 
Table 1 Germplasm evaluated.

LEGUMES

GRASSES

\section{White Clovers}

Grasslands Hula: Bred from persistent New Zealand ecotypes.

Grassland Tahora: Selected from ecotypes for moist hill country.

Grasslands Pltau: A winter-active Spanish/New Zealand cross.

Grasslands Kopu: Large-leafed and up-right. Bred for high summer growth

Italy $x$ NZ: Upright-large-leafed, cool season activity.

Halfa: Selection from Israel.

Clarence Valley: From Australia. Up-right and large-leafed

Tamar: From the Netherlands. Extreme up-right and large-

leafed.

Whatawhata: Now called Prop. Selected for dry North Island hill country.

C-6214: (Widdup). For pre-release. Southland white clover cultivar.

SI: From Louisanna, USA. Up-right and large-leafed.

Dusl: A South African variety with distinctive leaf mark.

\section{Alsike Clovers}

Tetra: A Swedish tetraploid available from Pyne Gould Guinness.

Dawn: A Canadian variety.

Aurora: A Canadian variety.

ISO-4N: A tetraploid from Finland.

USSR: A Russian variety.

Mackenzie/Ben Ohau: A naturalised selection from the Mackenzie country.

Grasslands: A mixture of lines from Grasslands DSIR selection programme.

Red Clover

Grasslands Pawera: A late flowering tetraploid.

\section{Lotus Corniculatus}

Granger: A semi-erect hay type from USA.

Guelph: A Canadian variety, fined stemmed and fast regrowth after cutting.

Emplre selection: (Scott). A Mackenzie country selection of United States Empire.

Maltland selection: A Mackenzie country selection of the Canadian Maitland.

Lotus Hybrid

G-4712: Lotus pendunculatus $\boldsymbol{x}$ Lotus corniculatus hybrid.

Chile mixture: A mixture of diploid ecotypes from dry areas

within Chile.

Grasslands Yaku: A Portuguese tretaploid adapted to moist low fertility soils.

G-4702: A tretaploid New Zealand selection. No Portuguese parentage.

Caucasian clover

Monaro: Hexaploid Caucasian clover.

\section{Ryegrasses}

Grasslands Nul: Highly productive. Withstands severe grazing and treading.

Grasslands Ruanul: Withstands severe grazing and treading. PG.I: A Pyne Gould Guinness selection. Released as 'Marathon'

PG.2: A Pyne Gould Guinness selection from Marlborough. PG.84F: A Pyne Gould Guinness selection from North Canterbury.

PG.84H: A Pyne Gould Guinness from a Dutch perennial.

PG.84M: A Pyne Gould Guinness New Zealand and European crossed selection.

PG.84R: A Pyne Gould Guinness selection from Banks Peninsular.

PG.84W: A Pyne Gould Guinness selection from Canterbury. New Zealand/Sweden: A PGG cross from New Zealand and Swedish material.

PG.84L: A Pyne Gould Guinness selection for medium'to late flowering.

Bar LP.82F: A Challenge Seeds selection from the Netherlands.

Tara Hills Sunny: A high endophyte selection from sunny aspects at Tara Hills.

Tara Hills Shady: Persistent ryegrass selected from the grazing trial.

Mackenzle/Central: A selection from the Mackenzie Basin and Central Otago.

Tall Fescues

Grasslands Roa: Crosses amongst Australian, USA and North African material.

Nomad: A Pyne Gould Guinness selection from Portuguese material.

Arondae: A Pyne Gould Guinness selection from French and English cultivars.

Bromes

Grasslands Tlkl: A winter dormant selection from European material.

Grasslands Hakari: A summer growing up-right, free seeding grass.

Grasslands Matua: Prairie grass. Good out of season production. Free seeding.

Cockstoots

Grasslands Wana: From spanish material. Prostrate and rust resistant.

Grasslands Apanul: Standard cultivar bred from selected New Zealand plants.

Tare Hills: (JA Douglas). A survivor from early trials on Acheron soils.

Others

Black Mountain rye: (CSIRO). A perennial ryecorn type from the Middle East.

Tall oat grass (Tara): Selection from persistent plants at Tara Hills.

Massey Basyn fog: Yorkshire fog selected at Palmerston North.

Sheep's burnet: A drought tolerant and frost tolerant herb with a strong tap root. 
were spread between spring 1984 and spring 198.5. The transplanted material was given at least 6 weeks to establish before grazing treatments begun. All material was 'watered in' by hand when first planted. In the first spring after planting, those rows with less than 5 surviving plants were replanted with freshly propagated material to overcome problems of transplant failure.

The top and bottom points of each row of plants were permanently marked with metal tabs, and in subsequent years a metal detector was used for relocation. In each October, prior to the start of grazing treatments, all rows were assessed for plant survival, that is number of plants surviving out of a possible of 16. In addition the lateral spread $(\mathrm{cm})$ of creeping varieties was noted by measuring the total horizontal width of surviving plants from at least 5 random points down each row.

Three of the nine grazing management treatments within the grazing trial have been chosen to represent a range of managements to simplify data presentation. These are: Lax (low Stocking rate/alternating grazing), Optimal (medium stocking rate/alternating grazing, the management giving optimal stock liveweight gain/ha) and Extreme (high stocking rate/continuous stocking) grazing managements.

\section{Results}

\section{Plant survival}

In general the legumes tested showed poor persistence, particularly under Extreme grazing (Table 2). White clover persistence was reasonable under Lax grazing, but poor under Extreme grazing. Of the 12 white clovers tested, none showed greater persistence after 5 years than-Huia-The only exception was a higher $(\mathrm{P}<0.05)$ persistence of C-6214 (Widdup) under Extreme grazing. Tetra alsike (Pyne Gould Guinness) showed better $(\mathrm{P}<0.05)$ persistence than a Mackenzie/Ben Ohau selection under Lax management, but was no better under Optimal and Extreme grazing. None of the lotus species persisted any better than the aliskes or red clover. Caucasian clover was the only clover to persist better $(\mathrm{P}<0.05)$ under Optimal and Extreme grazing than white clover (Table 2).

The cocksfoots and tall oat grass were the most outstanding grasses \{Table 2). Overall, Wana did not show greater persistence than Apanui, although under Extreme grazing the advantage of Wana over Apanui approached significance. Tall oat grass showed very good persistence, especially under Optimal and Extreme management. Grazing management had the opposite effect on ryegrass persistence compared with that of white clover. Unlike white clover, ryegrass persisted best under Extreme grazing, and very poorly under Lax
Table 2 Effects after 5 years (October 1990) of various grazing treatments on plant survival (maximum possible $=16$ ) of selected cultivars.

\begin{tabular}{lccc}
\hline & \multicolumn{3}{c}{ Tussock } \\
& Lax & Optimal & Extreme \\
\hline Hula white clover & 6.25 & 6.75 & 0.5 \\
C6214 white & 6.0 & 6.75 & 4.0 \\
Pawera red clover & 0.5 & 0 & 0 \\
Alsike (Mackenzie/Ben Ohau) & 0.25 & 0 & 0 \\
Tetra Alsike & 4.5 & 0 & 0.5 \\
Caucasian Clover & 10.75 & 12.5 & 11.00 \\
Nui ryegrass & 1.25 & 3.75 & 8.0 \\
PG2 ryegrass & 1.5 & 9.75 & 0.75 \\
PG 84F ryegrass & 0.5 & 7.75 & a.2 \\
Marathon ryegrass & 0 & 6.5 & 8.00 \\
Tara Shady ryegrass & 2.0 & 0.5 & 7.25 \\
Roa tall fescue & 2.5 & 6.25 & 5.0 \\
Nomad tall fescue & 0.25 & 1.00 & 1.75 \\
Aronde tall fescue & 3.25 & 6.25 & 4.25 \\
Tiki brome & 0 & 0.33 & 0.5 \\
Wana cocksfoot & 9.5 & 12.25 & 12.5 \\
Apanui cocksfoot & 8.5 & 11.75 & 0.75 \\
Tara cocksfoot & 13.25 & 13.5 & 6.75 \\
Tall oat grass & 6.0 & 9.0 & 9.75 \\
\hline
\end{tabular}

For comparisons between Huia, C6214, Tetra Alsike and Caucasian, Isd $(5 \%)=2.91$

For comparisons between Alsike and Huia, C6214, Tetra and Caucasian, Isd $=2.14$

For comparisons between Nui, PG2 and PG84F, Lsd (5\%) $=3.51$ For comparisons between Tara shady, Nui, PG2 and PG84F, Isd $(5 \%)=4.36$

For comparisons between Tara shady, Marathon, Nui, PG2 and PGB4F, Isd $(5 \%)=4.23$

For comparisons between Roa and Nomad, Isd $(5 \%)=2.33$

For comparisons between Road and Aronde, Isd $(5 \%)=3.97$

For comparisons between Nomad and Aronde, Isd $(5 \%)=3.66$

For comparisons between all Cocksfoots and tall oat grass, Isd $(5 \%)=4.02$

grazing (Table 2). None of the ryegrasses tested showed greater persistence than Nui ryegrass. However, two of the Pyne Gould Guinness selections, PG-2 and PG84F, and the Tara Shady selection, showed better $(\mathrm{P}<0.05)$ persistence than Nui under Optimal management. Although not significant, Pyne Gould Guinness Marathon ryegrass appeared to persist better than Nui under Optimal grazing. The three tall fescues did not persist any better than Nui, although Roa and Aronde survival was superior $(\mathrm{P}<0.05)$ to that of Nomad under Optimal grazing. Survival of all bromes tested was poor, but of them Tiki was the best (Table 2).

\section{Plant spread}

Caucasian clover was the only material tested to show signifcant spread from the original planted row. The extent of horizontal spread of this species was recorded from spring 1988 (that is four years after transplanting) through to spring 1993 (Figure 1). By spring 1993, nine 
years after transplanting, Caucasian clover spread averaged $58.2 \mathrm{~cm}$ across all nine grazing treatments (Table 3). The greatest spread for any one plant was $138 \mathrm{~cm}$ recorded under the high stocking/rotational grazing management treatment. By 1993, the spread was greater under optimal than lax grazing. The spread appeared greater under high and medium stocking rates than low, and greater under alternating and rotational grazing than continuous stocking. The apparent main effect differences were not significant because of interactive forces between stocking rate and grazing management (Table 3).

Figure 1 Spread of Caucasian clover under Lax, Optimal and Extreme grazing (from the Tars Hills grazing trial).

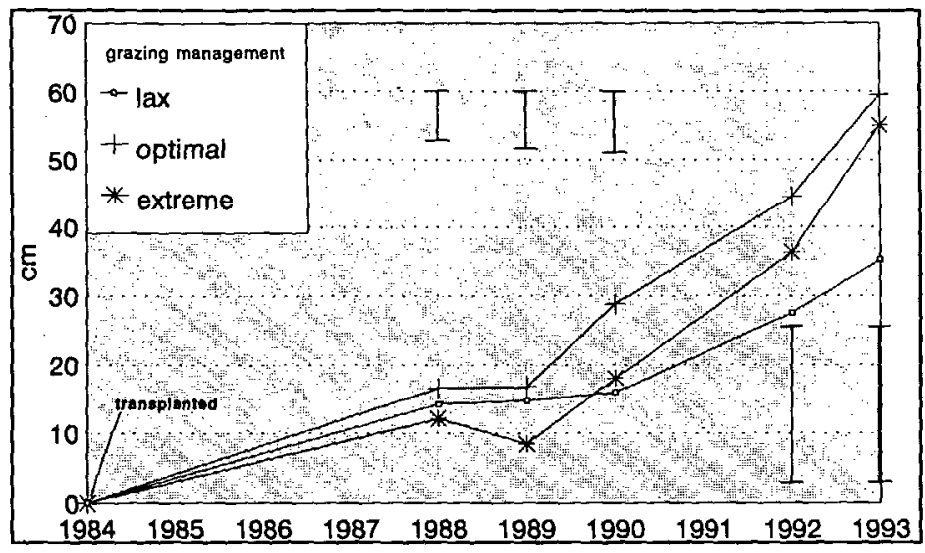

Table 3 Effects of grazing management on the horizontal spread of Caucasian clover plants 9 years after transplanting (recorded October 1993). Spread (cm) represents mean lateral width of plants.

\begin{tabular}{lcccc}
\hline & \multicolumn{4}{c}{ Stocking Rate } \\
& Low & Medium & High & Mean \\
\hline Grazing practice: & & & & \\
$\quad$ Continuous & 47.5 & 65.0 & 55.0 & 55.9 \\
Alternating & 35.2 & 59.2 & 66.0 & 54.2 \\
Rotational & 49.7 & 64.2 & 79.5 & 84.5 \\
Mean & 44.2 & 62.9 & 67.5 & 56.2 \\
\hline
\end{tabular}

LSD $(5 \%)$ (stocking rate . grazing practice) $=23.3$

\section{Discussion and conclusions}

Caucasian clover has clearly been the outstanding legume in this study. Lowther \& Patrick (1992) reported good establishment and seedling vigour of Caucasian clover provided rhizobial inoculation was adequate. This study has shown that once established, Caucasian clover will not only survive as a young plant, but persist and spread under optimal and even extreme grazing. Woodman et al. (1992) have shown from trials on low-altitude sunny landscapes at Tara Hills that this legume has a high tolerance to drought. The main advantages of Caucasian clover over other more traditional legumes are its rhizomatous habit, and that its growing points are underground and therefore protected from grazing. This underground spreading ability has been reported elsewhere (Moorhouse 1994), but this study has shown that spread will occur despite a large range in management conditions. Caucasian clover, unlike white clover (Allan et al. 1992), will survive and even spread under the high grazing pressure that often occurs during dry seasons in the high country.

This study has re-emphasised the value of cocksfoot as a persistent grass for oversown tussock grassland. There appears to be an advantage to the prostrate Wana over the more upright Apanui in terms of persistence, but only if high levels of pasture utilisation are intended. Likewise, on fertile high country soils where ryegrass will establish, Marathon ryegrass is likely to be more persistent than Nui if Optimal management is intended. Of all the grasses tested, only tall oat grass matched the persistence of cocksfoot across all management treatments. Tall oat grass is a droughtand low-fertility-tolerant grass that, when managed well, is similar to cocksfoot in production and palatbility (Wills \& Begg 1994). This study has shown that, like cocksfoot and Caucasian clover, tall oat grass is tolerant of the lax to extreme range of grazing that typically occurs under extensive mangement of grasslands in a difficult and variable climate.

\section{ACKNOWLEDGEMENTS}

Tara Hills and Invermay staff for assistance in propagation and transplanting. Richard Doney and Hazel Chapman for technical help, and Peter Johnston and Lesly Hunt for biometric advice.

\section{REFERENCES}

Allan,B.E.:Lowther, W.L.; Walton, P.J. 1985. Planning, establishment and management of pastures in high country. Chapter 2. In: Burgess, R.E.; Brock, J.L., editors. Using herbage cultivan. Grasslands 
Research and Practice Series No. 3, New Zealand Grassland Association, Palmerston North.

Allan, B.E.; Keoghan, J.M. 1989. Better utilisation of oversown tussock grassland in the semi-arid country of New Zealand. Proceedings of the XVI International Grassland Congress: 12.57-1258.

Allan, B.E.; O'Connor, K.F.; White, J.G.H. 1992. Grazing management of oversown tussock country 2. Effects on botanical composition. New Zealand journal of agricultural research 35: 7-19.

Kerr, I.G.C. 1983. Production, performance and prospects in the high country. Proceedings of the 1983 Hill and High Country Seminar, Lincoln College p. 19-26

Lowther, W.L.; Patrick, H.N. 1992. Seedling establishment characteristics of alternative legume species in tussock grassland environments. Proceedings of the New Zealand Grassland Association 54: 11 1 - 114.

Moorehead, A. 1994. Effect of sowing method and fertiliser application on the establishment of
Caucasian clover. Proceedings of the New Zealand Grassland Association 56: this volume.

O'Connor, K.F. 1967. The improvement and utilisation of tussock grasslands: a scientists viewpoint cylcing nitrogen for production. Proceedings of the New Zealand Grassland Association 28: 59-78.

Vartha, E.W.; Clifford, P.T.P. 1973. Improvement of mid-altitude tussock grassland for grazing by topdressing and oversowing. New Zealand journal of experimental agriculture I: 181 - 186.

Woodman, R.F.; Keoghan J.M.; Allan B.E. 1992. Pasture species for drought-prone lower slopes in the South Island high country. Proceedings of the New Zealand Grassland Association 54: 115- 120.

Wills, B.J.; Begg, J.S.C. 1994. Arrhenatherum elatis (L.) Beauv. -tail oat grass: a review of its utilisation, and its selection for dryland and hawkweed country in Central Otago. Proceedings of the New Zealand Grassland Association 56: this volume. 